NR 20 (29)

BIBLIOTEKA

2016 PL ISSN 1506-3615

$\begin{array}{lllllllll}\mathrm{P} & \mathrm{R} & \mathrm{Z} & \mathrm{E} & \mathrm{K} & \mathrm{E} & \mathrm{A} & \mathrm{D} & \mathrm{Y}\end{array}$

JESPER DÜRING JØRGENSEN

Biblioteka Królewska w Kopenhadze

\title{
Anatomia przestępstwa. 25 lat minęło. Interesujący przypadek kradzieży książek i wykrycia zbrodni po latach ${ }^{1}$
}

11 września 2003 roku niczym się nie różnił od innych dni roboczych w Bibliotece Królewskiej w Kopenhadze, przynajmniej przez pierwszych kilka godzin poranka. Około godziny 11.00 spokój został nagle przerwany odgłosem dzwonka telefonicznego. Uprzejmy głos kobiecy w słuchawce należał do specjalistki od starodruków z londyńskiego oddziału domu aukcyjnego Christie's. Kobieta poinformowała mnie, że anonimowy sprzedawca działający przez konsygnatariusza wystawił właśnie na aukcję następujące dzieło: Propalladia de Bartholome de Torres Naharro. Dirigida... Napoles: por Ioan Pasqueto de Sallo, wydane w Neapolu w roku 1517. Po sprawdzeniu katalogu dzieł Torresa Naharro z 1943 roku przedstawicielka domu aukcyjnego ustaliła, że znane są zaledwie dwa egzemplarze starodruku, które dotrwały do naszych czasów. Jeden, niekompletny egzemplarz, miał być przechowywany w Hiszpańskiej Bibliotece Narodowej, podczas gdy drugi, kompletny, miał się znajdować w Bibliotece Królewskiej w Kopenhadze. Ta informacja zaintrygowała panią kustosz z domu aukcyjnego i oto, nie wiedząc, czy ma do czynienia z historycznym odkryciem, czy też z przypadkiem zwykłej kradzieży książek, zdecydowała się zatelefonować do naszej biblioteki.

${ }^{1}$ J.D. Jørgensen, The Anatomy of a Crime Discovery after 25 Years. A Notable Case of Book Theft and its Detection, "LIBER Quarterly” 2007, nr 17 (1), http://doi. org/10.18352/lq.7874. Niniejszy artykuł charakterem odbiega od tekstów zamieszczanych w "Bibliotece”, jest raczej literackim reportażem niż naukową rozprawą. Te jego właściwości stylistyczno-gatunkowe zadecydowały o tym, że zrezygnowaliśmy z poprzedzenia go streszczeniem. Drukujemy go ze względu na ciekawą problematykę: kradzieże rzadkich książek to palący problem wszystkich bibliotek na świecie. Artykuł prezentuje historię odzyskania skradzionych starodruków z Biblioteki Królewskiej w Kopenhadze. 
Niestety musiałam poinformować ją że ten niezwykle rzadki starodruk figuruje $u$ nas jako zaginiony i że jego zaginięcie ze zbiorów Biblioteki Królewskiej odnotowano 28 lutego 1979 roku. To właśnie tego dnia przeprowadzane skontrum zbiorów starych druków wydanych za granica, spowodowane godnym pożałowania faktem stwierdzenia kradzieży w Bibliotece Królewskiej w latach 70. XX wieku, dotarło do pozycji sygnatur z tomu 18 (s. 36) w katalogu systematycznym biblioteki. Sygnatura katalogowa jest także sygnaturą umieszczaną bezpośrednio na książce, zapytałam więc, czy na egzemplarzu z domu aukcyjnego są ślady oznaczenia bibliotecznego znajdującego się zwykle w lewym rogu wewnętrznej strony oprawy. Pierwsza odpowiedź była przecząca, ale gdy poprosiłam moją rozmówczynię, aby uniosła książkę i przechyliła pod światło, okazało się, że jest w stanie dostrzec ślady po kilku cyfrach. Było oczywiste, że ktoś próbował zatrzeć sygnaturę Biblioteki Królewskiej. Pozostały jednak ślady i gdy ustawiło się książkę pod właściwym kątem pod światło, dało się odczytać: 18, - 36.

Była to pamiętna chwila. Przez 30 lat policja i dział bezpieczeństwa zbiorów Biblioteki Królewskiej bezskutecznie usiłowały natrafić na jakikolwiek trop czy to złodzieja, który - jak uważano - był pracownikiem biblioteki, czy to zaginionych książek, które nie pojawiły się na rynku. Do tamtego dnia nie byliśmy w stanie zidentyfikować pośród druków pojawiających się na aukcjach, czy w publikowanych katalogach, żadnego ze skradzionych tytułów. W trakcie naszej rozmowy telefonicznej okazało się także, że ten sam pośrednik dostarczył wcześniej trzy inne książki z przeznaczeniem na sprzedaż, wśród nich wydanie dzieła Lutra z 1525 roku, które też figurowało na liście zaginionych dzieł z naszych zbiorów wczesnych druków z czasów reformacji luterańskiej. Oprawa tego egzemplarza została opatrzona pieczątką z duńskim herbem narodowym, co jest zwyczajową praktyką stosowaną dla wszystkich książek przechowywanych w Bibliotece Królewskiej. Po kilku następnych rozmowach telefonicznych i po otrzymaniu faksu ze zdjęciami, które przedstawiały charakterystyczne elementy opraw interesujących nas dzieł oraz umieszczane na nich pieczęcie, poinformowałam dyrektora naczelnego Biblioteki Królewskiej o tym nadzwyczajnym odkryciu, które rzuciło nowe światło na zadawnioną i do tej pory niewyjaśnioną kradzież. Choć sprawa była pilna, kontakt z dyrektorem nie okazał się wcale taki prosty. Erland Kolding Nielsen, dyrektor Biblioteki Królewskiej, uczestniczył właśnie w ważnym spotkaniu w Jutlandii, na którym omawiano przyszłość polityki kulturalnej i rolę bibliotek naukowych w kraju. W końcu jednak podszedł do telefonu, a po krótkiej rozmowie natychmiast wydał mi polecenie jak najszybszego wyjazdu do Londynu. Chociaż było to 
raczej mało eleganckie zachowanie wobec domu aukcyjnego Christie's, postanowiłam, że zabiorę ze sobą specjalistkę od starych druków, odpowiedzialną za przeprowadzane skontrum zbiorów obcych. Dzięki temu zyskałam dodatkowego świadka i jednocześnie wysokiej klasy eksperta. Nikt bowiem w naszej bibliotece nie miał do czynienia z tyloma rzadkimi starodrukami co ona.

Jeszcze przed wyjazdem skontaktowałam się z szefem lokalnego biura Interpolu w Kopenhadze i poinformowałam go o odkryciu w domu aukcyjnym Christie's książek skradzionych z naszej biblioteki. Chodziło mi o to, żeby, korzystając z pośrednictwa Interpolu, zawiadomić o wszystkim Scotland Yard na wypadek, gdyby pojawiły się jakiekolwiek komplikacje w domu aukcyjnym. Cztery dni później, 15 września, w domu aukcyjnym Christie's pokazano nam nie tylko cztery książki, ale w sumie 16, tj. wszystkie te, które zostały dostarczone przez tego samego pośrednika. Nie będę ukrywać: pierwszą rzecza, którą byliśmy zainteresowani, to ujawnienie jego tożsamości. Niestety wszelkie nasze wysiłki nakłonienia do tego naszych rozmówców, czy to taktownymi zapytaniami, czy już bardziej stanowczymi naleganiami i próbami przekonania, na nic się zdały. Na koniec zdecydowałam się zadzwonić do przedstawicielstwa Interpolu w Kopenhadze, co zaowocowało wykonaniem kolejnego telefonu do Oddziału ds. Sztuki i Antyków w Scotland Yardzie. W naszych negocjacjach z domem aukcyjnych udało się tymczasem uzyskać zapewnienie od tamtejszego szefa ochrony, że książki pod żadnym pozorem nie zostaną zwrócone pośrednikowi lub też sprzedane. Mogliśmy bowiem udowodnić, że przynajmniej jedna z 16, które widzieliśmy, pochodzi z naszych zbiorów.

W trakcie pracy jako główny doradca do spraw bezpieczeństwa zbiorów w bibliotece często miałam do czynienia ze skradzionymi książkami czy innymi obiektami wyprowadzonymi z biblioteki. Niemal zawsze skradzione woluminy wyglądają na podniszczone i jest to w zasadzie całkiem zrozumiałe, bo zwykle przechodzą przez wiele chciwych rąk. A jednak okazane nam książki były wyraźnie bardzo zadbane. Wyglądały, jakby dopiero co zostały przyniesione z półek Biblioteki Królewskiej, choć to oczywiście było absolutnie niemożliwe, ponieważ nie było ich w naszych zbiorach już od ponad 30 lat. Patrząc na stan książek, nie mogłam wręcz oprzeć się wrażeniu, że w całej tej sprawie musi być jakiś duński ślad, chociaż zapewniano nas, że pośrednik jest Brytyjczykiem. Była to jedyna informacja, jaką udało nam się uzyskać. Po powrocie do Kopenhagi ponownie spotkałam się z dyrektorem Nielsenem, a nasza konferencja podsumowana została formalnym zgłoszeniem policji faktu kradzieży. Do zgłoszenia dołączyliśmy stosowny dokument, w którym dowodziliśmy, 
że wszystkie wymienione $\mathrm{w}$ nim książki zostały skradzione z Biblioteki Królewskiej. Byliśmy też w tej szczęśliwej sytuacji, że mogliśmy dostarczyć kilka dowodów dla każdej z książek, jasno wykazujących prawo własności Biblioteki Królewskiej.

Sprawa nie była jednak taka prosta. Od razu napotkaliśmy trudności. Książki skradziono ponad 10 lat wcześniej, zatem w świetle praktyki prawnej w Danii kradzież uznano za przedawnioną i nie podlegała ona ściganiu z mocy prawa. Dochodzić swoich racji mogliśmy - tak nam doradzono - na drodze pozwu prywatnego. Było to oczywiście nie do przyjęcia i twardo argumentowaliśmy, że sprawa może być przecież potraktowana przynajmniej jako paserstwo towarami skradzionymi. To były dramatyczne godziny, między innymi zagroziliśmy, że nadamy sprawie publiczny rozgłos. $W$ rezultacie nasz punkt widzenia został wreszcie zaakceptowany przez władze zwierzchnie policji i 23 września sprawa została skierowana do prokuratury. To z kolei umożliwiło władzom duńskim przesłanie oficjalnej prośby sądowej (pisma rekwizycyjnego) do Scotland Yardu w Londynie o udzielenie stosownej pomocy prawnej w celu nakłonienia domu aukcyjnego Christie's do przekazania następujących informacji: tożsamości pośrednika, dokumentacji wcześniejszych transakcji biznesowych z tym samym pośrednikiem, dokumentów przewozowych dla przesłanych książek i dokumentacji z firm przewozowych, nazwisk i adresów kupców książek wcześniej dostarczonych przez pośrednika, a następnie sprzedanych przez dom aukcyjny Christie's.

W trakcie tych negocjacji dyrektor Nielsen zadecydował o digitalizacji drukowanego katalogu zaginionych ksiąg z Biblioteki Królewskiej i stworzeniu komputerowej bazy danych. Projekt został przeprowadzony w ciągu dwóch miesięcy, ze względu na dyskrecję, jaką musieliśmy zachować, wykonany został pod pretekstem otrzymania przez bibliotekę dodatkowych i niespodziewanych funduszy do natychmiastowego wykorzystania. 8 października odebrałam telefon od oficera policji z komendy głównej policji duńskiej, który poinformował mnie, że pośrednikiem jest kobieta nosząca nazwisko Silke Albrecht. Najwyraźniej była Niemką i mieszkała w małym miasteczku Lindenberg w Bawarii. Wszystkie ustalenia dotyczące sprzedaży pomiędzy nią a domem aukcyjnym dokonywane były telefonicznie i, jak mnie poinformowano, od roku 1998 Silke Albrecht sprzedała poprzez dom aukcyjny Christie's znaczną liczbę rzadkich starodruków. Za każdym razem książki wysyłano z Lindenbergu, korzystając z pośrednictwa firmy przewozowej z Monachium. Stanowiło to dla mnie zagadkę. Zwykle skradzione książki są mocno podniszczone i w mniejszym lub większym stopniu uszkodzone, tymczasem 16 książek, 
które oglądaliśmy w siedzibie Christie’s, były - jak już wcześniej wspomniałam $-\mathrm{w}$ bardzo dobrym stanie.

Moje poszukiwania zaczęłam od przewertowania stron internetowych w nadziei odnalezienia jakiegoś śladu w Danii. Nazwisko Silke Albrecht jest całkiem pospolite w Niemczech, ale rzadkie w Danii. I oto nagle właśnie to nazwisko pojawiło się na duńskiej stronie serwisu internetowego MSN-Denmark. Wyglądało na to, że Silke Albrecht była członkiem klubu maratońskiego w Elsynorze i wzięła udział w małym biegu maratońskim (jedna czwarta dystansu maratońskiego). Następnym krokiem było odszukanie jej adresu w książce telefonicznej, co było już całkiem proste. Według książki telefonicznej osoba o tym imieniu i nazwisku zajmowała mieszkanie w miejscowości Elsynor. Biblioteka Królewska posiada prawo do egzemplarza obowiązkowego od roku 1697, co oznacza, że otrzymuje praktycznie prawie wszystkie publikacje drukowane w Królestwie Danii. Teraz pozostało jedynie sprawdzenie spisu abonentów numerów telefonicznych dla miasta Elsynor na rok 2002 i, zgodnie z przedstawioną informacją stwierdzenie, że Silke Albrecht mieszka na ulicy Steenwinkels Vej, ale nie samotnie. W spisie abonentów znalazły się bowiem dodatkowe wskazówki: mieszkała razem z mężczyzną o nazwisku Thomas Møller-Kristensen. To nazwisko dobrze znaliśmy. Nosił je nasz były kolega z pracy, który w roku 2000 przeszedł na emeryturę, a w styczniu 2003 roku zmarł w swoim domu w Espergaerde, leżącym niedaleko Elsynoru. W bibliotece był zatrudniony od roku 1967 aż do emerytury. W latach 1967-1987 kierował Działem Orientalnym, od roku 1987 pracował jako bibliotekarz naukowy specjalizujący się w kulturze i językach Indii, był bowiem ekspertem od klasycznego języka palijskiego. Wszystko wskazywało jednak na to, że miał też inne zainteresowania, o których nikt $\mathrm{w}$ bibliotece nie wiedział. $\mathrm{W}$ trakcie krótkiej rozmowy $\mathrm{z}$ jednym $\mathrm{z}$ pracowników biblioteki, z którym współpracował Frede Møller-Kristensen, szybko ustaliłam, że Frede miał syna o imieniu Thomas. W tym momencie przypomniałam sobie początek mojego zatrudnienia w Bibliotece Królewskiej w latach 70 . W tym czasie byłam odpowiedzialna za magazyny w Dziale Duńskim i w związku z tym dołączono mnie w 1973 roku do komisji do spraw bezpieczeństwa zbiorów. Komisję tę powołano po przykrych doświadczeniach z lat wcześniejszych, kiedy okazało się, że całkiem spora liczba cennych i rzadkich starodruków ze zbiorów zagranicznych zaczęła w tajemniczy sposób znikać bez śladu z półek. Poinformowano o tym fakcie policję i przeprowadzono dyskretne poszukiwania książek w antykwariatach na terenie Danii i za granicą. Dyrektor Biblioteki Narodowej powiadomił o kradzieży swoich kolegów w Europie i w Stanach Zjednoczonych, ale żadne z tych działań nie przyniosło wyników. 


\section{Identyfikacja złodzieja}

Pod koniec lat 70. ubiegłego wieku komisja do spraw bezpieczeństwa zbiorów w Bibliotece Królewskiej opracowała obszerny i wszechstronny system zabezpieczeń, które miały zapobiec dalszym stratom w zbiorach i, faktycznie, od roku 1978 nie notowano zaginięć. Wcześniejsze kradzieże nie zostały jednak wyjaśnione. Podejrzewano kilka osób, byli nawet przesłuchiwani przez policję, co wytworzyło niemiła, pełną wzajemnych podejrzeń atmosferę, która utrzymywała się przed kilka dobrych lat.

Teraz, 8 października 2003 roku, miałam wreszcie możliwość ustalenia tożsamości złodzieja, który przez całe lata powodował tak zatrważające straty w zbiorach Biblioteki Królewskiej i wyrządził tyle szkody swoim ówczesnym kolegom z pracy. Kolejna chwila godna zapamiętania. Przeprowadzono kilka następnych weryfikacji, aby wykluczyć pomyłkę i jakiekolwiek wątpliwości dotyczące rzeczywistych rodzinnych powiązań obu mężczyzn. Zbieżność nazwisk mogła być przypadkowa, ale już krótkie dochodzenie potwierdziło, że mamy do czynienia z ojcem i synem oraz że Silke była żoną Thomasa i - co więcej - że w międzyczasie młode małżeństwo zamieniło skromne mieszkanie w Elsynorze na dom w Ålsgårde, atrakcyjnej miejscowości na północnym wybrzeżu Zelandii, niedaleko od Elsynoru i Espergaerde, gdzie mieszkał Frede Møller-Kristensen ze swoją żoną Evą Møller-Kristensen, dziś wdową.

Próbowałam skontaktować się z tym samym oficerem policji, z którym współpracowaliśmy na początku ujawnienia kradzieży we wrześniu. Okazało się jednak, że był bardzo zajęty: prowadził jakąś paskudną sprawę rozboju połączonego z próbą morderstwa. Dwóch uchodźców z Kuby tego samego popołudnia dokonało rozboju na poczcie w Kopenhadze i postrzeliło urzędniczkę. Udałam się do dyrektora Nielsena i przekazałam mu informacje na temat dotychczasowych ustaleń w sprawie złodzieja z lat 70. Oboje byliśmy zaskoczeni i zdumieni tym odkryciem. Podczas całej swojej kariery bibliotecznej Frede Møller-Kristensen sprawiał wrażenie spokojnego, nieco nieobecnego duchem naukowca filologa, niezbyt zdolnego administratora, ale za to niezwykle, może nawet nazbyt, skłonnego do wypicia od czasu do czasu kufelka piwa. To ostatnie było zresztą powodem zwolnienia go z obowiązków kierownika Oddziału Orientalnego w roku 1987. W każdym razie teraz nie tylko mogliśmy wreszcie wyjaśnić zadawnioną sprawę kradzieży z Biblioteki Królewskiej, ale też odkryliśmy sprawcę, choć nie żył już od kilku lat.

Następnym krokiem było uzyskanie sądowego nakazu rewizji, co okazało się całkiem skomplikowane, bowiem prawo, co oczywiste, musi chronić prywatność i własność obywateli. W tym przypadku jednak 
posiadaliśmy tak mocne dowody na to, że wskazani przez nas ludzie przekroczyli prawo, że sąd przychylił się do naszej prośby i wydał nakaz rewizji w mieszkaniu wdowy po naszym byłym pracowniku oraz w domu Silke Albrecht i Thomasa Møller-Kristensena. Co więcej, zadecydowano, że zostanie przeprowadzona także rewizja w Lindenbergu i Monachium w Niemczech. W trakcie dochodzenia ustalono bowiem, że książki były najpierw przewożone z Danii do Lindenbergu w Bawarii, skąd wysyłano je - za pośrednictwem wyspecjalizowanej firmy - do domu aukcyjnego Christie's w Londynie. To z kolei wskazywało na konieczność dokonania przeszukań również w siedzibie firmy. Ze względu na fakt, że Niemcy są krajem federalnym, trochę czasu upłynęło, zanim udało nam się uzyskać konieczne nakazy rewizji od władz federalnych i lokalnych. Wreszcie pod koniec października 2003 roku wszelkie niezbędne formalności zostały załatwione. W międzyczasie, $\mathrm{w}$ towarzystwie oficera duńskiej policji, złożyłam wizytę w Scotland Yardzie, aby uzyskać dalszą dokumentację wszystkich transakcji pomiędzy Silke Albrecht a domem aukcyjnym Christie's. Ponad to udało nam się zdobyć kopie rachunków i dokumentów sprzedażnych starodruków wstawianych na aukcje w imieniu Silke Albrecht, która, według wiedzy domu aukcyjnego, miała mieszkać w Lindenbergu. Adres domowy matki Silke Albrecht, Theresy Albrecht, został więc wykorzystany jako przykrywka dla interesów prowadzonych przez córkę. Okazało się, że Silke Albrecht sprzedała, lub próbowała sprzedać, w domu aukcyjnym Christie's 36 książek za sumę 415540 funtów brytyjskich.

Zdecydowano, że 5 listopada 2003 roku odbędą się przeszukania, zarówno w Danii, jak i w Niemczech. Kradzieże książek antykwarycznych nie są może szczególnym i częstym przedmiotem zainteresowania dunskiej policji, ale ten konkretny przypadek wydawał się całkiem nadzwyczajny, co można było ocenić po wartości 16 skradzionych starodruków odkrytych w domu aukcyjnym. Jako koordynator sprawy z Biblioteki Królewskiej zostałam poproszona o wskazanie specjalisty od starodruków, który mógłby pomóc policji w zidentyfikowaniu książek należących do Biblioteki Królewskiej. Mój wybór padł na bibliotekarkę, która była kierownikiem grupy rewizyjnej dokonującej przeglądu zbiorów. Nikt inny $\mathrm{w}$ bibliotece nie widział i nie trzymał $\mathrm{w}$ dłoniach tylu rzadkich starodruków co ona, a ponadto była doskonale zorientowana w różnorodności naszych zbiorów. I wreszcie, co nie jest bez znaczenia, nie można jej było w żaden sposób łączyć z osobą złodzieja czy popełnionymi kradzieżami. Choć teraz znaliśmy już tożsamość sprawcy, nadal nie wiedzieliśmy, czy kradzieże nie miały związku z innymi pracownikami biblioteki, którego nie byliśmy świadomi. Było więc niezwykle ważne, aby o wszystkich 
naszych zamiarach wiedział jak najwęższy krąg osób. Zadecydowano więc, że Susanne Budde, którą wskazałam, weźmie udział w przeszukiwaniach w Danii i że ja będę jej pomagać w Niemczech. Władze niemieckie sprawiały wrażenie, jakby traktowały tę sprawę nieco mniej poważnie niż my w Danii.

4 listopada ja, dwóch duńskich policjantów z policji kopenhaskiej, dwóch oficerów łącznikowych policji duńskiej z Bundeskriminalamt w Wiesbaden, dwie osoby z Bundeskriminalamt w Monachium oraz dwóch przedstawicieli policji bawarskiej z Lindenbergu spotkaliśmy się w budynku Bundeskriminalamt w Monachium, aby omówić plan działania. Podczas spotkania poproszono mnie o przedstawienie sprawy z perspektywy Biblioteki Królewskiej. Zadecydowano, że przeszukiwania w Danii powinny rozpocząć się o 5 nad ranem, choć przedstawiciele policji niemieckiej nalegali, aby poczekać do godziny 10 rano, co utrudniało pracę duńskiej policji. W konsekwencji takiej decyzji trzeba bowiem podjąć dodatkowe działania uniemożliwiające podejrzanym z Danii jakikolwiek kontakt ze światem zewnętrznym, tak by nie mogli ostrzec swoich wspólników w Niemczech. Okazało się jednak, że takie rozwiązanie może być całkiem korzystne, ponieważ przystępując do rewizji w Niemczech, będziemy znali rezultaty przeszukiwań dokonanych w Danii.

Już podczas śniadania w hotelu w Lindau (kilka mil od Lindenbergu) sielankowo położonym mieście na niewielkim półwyspie nad Jeziorem Bodeńskim - w którym utworzyliśmy centrum naszej operacji w Niemczech, otrzymaliśmy informację, że w domu wdowy po Kristensenie odnaleziono w sumie ok. 1500 książek. Pięć rzadkich starodruków znaleziono w domu Silke Albrecht i Thomasa Møller-Kristensena w Ålsgårde. Były one już przygotowane do sprzedaży, tzn. usunięto z nich wszystkie ślady, które mogły je łączyć z Biblioteką Królewską. Tymczasem w Lindenbergu, w domu matki Silke Albrecht rewizja dała dość skromne wyniki: jedynie cztery książki, z których dwie zostały wcześniej zwrócone z domu aukcyjnego Christie's jako pozycje niesprzedane. Policja, co najważniejsze, odnalazła jednak kilka rachunków za książki wysłane do Londynu, a także kilka dość kompromitujących listów Silke Albrecht do matki, które niezbicie dowodziły, że matka i córka współpracowały w tym procederze. Theresa Albrecht została zabrana na komisariat policji w Lindenbergu, gdzie podczas trwającego dwie godziny przesłuchania wypytywano ją o stan jej wiedzy na temat interesów córki i zysków z prowadzonej działalności. O godzinie 11 rewizje zostały zakończone. Przeszukania w firmie przewozowej okazały się całkiem obiecujące, podobnie jak dochodzenia i informacje, jakie uzyskaliśmy w banku na temat kilku kont bankowych posiadanych przez Silke Albrecht w Niemczech. 
Zadzwoniłam do dyrektora, by opowiedzieć o wynikach dokonanych rewizji. Był zdumiony ich rezultatami! Ponieważ wcześniej, 31 października, był już poufnie powiadomiony przez policję kopenhaską o zbliżających się przeszukiwaniach, przygotował spotkanie $\mathrm{z}$ ministrem kultury na popołudnie 5 listopada, podczas którego mógł osobiście i wcześniej niż prasa poinformować ministra o naszych zaskakujących odkryciach. Jednocześnie minister sprawiedliwości został mniej więcej $\mathrm{w}$ tym samym czasie powiadomiony o sprawie przez komendanta policji kopenhaskiej, bowiem sprawę uznano za bardzo ważną ze względu na wartość zaginionych książek.

W Danii wdowa po Kristensenie, jej syn i synowa zostali zabrani na wstępne przesłuchania, po czym zostali zatrzymani $\mathrm{w}$ areszcie, gdzie pozostawali w izolacji bez możliwości kontaktowania się ze sobą i ze światem zewnętrznym, z wyjątkiem swoich adwokatów. Taka forma ograniczenia wolności jest, zwłaszcza w ostatnich latach, niezwykle dyskusyjna, może bowiem wywierać bardzo niekorzystny wpływ psychologiczny na osoby nią dotknięte. Jest jednak stosowana w przypadkach, gdy prokurator prowadzący sprawę i wstępne przesłuchania wskazują że niepozostający $w$ odosobnieniu podsądny może utrudniać rozwiązanie sprawy. Jest też prawdopodobnie stosowana $w$ celu zachęcenia zatrzymanego do przyznania się do zarzucanych czynów. Następnego dnia aresztowano także irlandzkiego przyjaciela rodziny po jego przyznaniu się zarówno do przewiezienia książek do Stanów Zjednoczonych, jak i do tego, że jego siostra w Nowym Jorku pomogła mu sprzedać książki w domu aukcyjnym Swann Galleries.

Od listopada 2003 roku do 1 lutego 2004 roku wszystkie książki odnalezione w domu należącym do wdowy po Kristensenie w Espergaerde zostały skatalogowane i opisane tak, by spełniały wszystkie wymagania konieczne do przekonania sądu, że były kiedyś własnością Biblioteki Królewskiej. To zadanie przekraczało oczywiście możliwości policji i w związku z tym zapytano mnie, czy Biblioteka Królewska mogłaby oddelegować specjalistów do dyspozycji policji. Zebrałam małą grupę bibliotekarzy specjalistów od starych i rzadkich książek, którzy mogli wykonać tę pracę. Co więcej, należało to zrobić w tajemnicy, aby nie utrudniać niepotrzebnie dalszego wyjaśnienia sprawy. To w konsekwencji oznaczało, że wszystkie książki musiały zostać zabrane do głównej siedziby policji w Kopenhadze, a dwóch oficerów policji zostało oddelegowanych do naszej dyspozycji, aby prowadzić dyskretnie działania zmierzające do przedstawienia sprawy w sądzie. Przede wszystkim konieczne było sporządzenie listy wszystkich 1665 odnalezionych książek i przedłożenie jej w sądzie. Każda książka otrzymała więc numer identyfikacyjny na 
umieszczonej w niej kartce oraz na liście, na której została skatalogowana: autor, tytuł i znak wydawcy oraz krótki opis wszelkich charakterystycznych cech (proweniencja, rzadkość, znak właściciela itd.). Dołączono także wskazówki dotyczące ewentualnej wartości rynkowej.

Wykonano po dwie fotokopie strony tytułowej, a numer książki zapisano na każdej z nich. Jedną z fotokopii umieszczono w egzemplarzu, drugą zabrano do biblioteki, gdzie dwóch bibliotekarzy sprawdziło sygnaturę, autora, tytuł i znak wydawcy w bazie zaginionych książek, zaznaczając każdy zapis dla znalezionego woluminu specjalnym kodem. Poza wyznaczonymi do tej pracy kolegami nikt inny w bibliotece nie został poinformowany o rozwiązaniu starej sprawy i zidentyfikowaniu przestępców. Co do książek, sukcesywnie pakowano je do pudełek i transportowano do jednego ze skarbców Biblioteki Królewskiej, nie było bowiem wystarczająco dużo miejsca w magazynach komendy głównej policji, gdzie przechowywano skradzioną własność. Nie oznaczało to, że woluminy zostały już uznane za własność Biblioteki Królewskiej, tyle tylko, że mogła ona teraz działać w imieniu policji i sądu.

Każdego późnego popołudnia od listopada 2003 roku do lutego 2004 roku, po powrocie z codziennej regularnej pracy na terenie komendy policji zdawałam dyrektorowi biblioteki raport z naszych nowych odkryć i dokonań. Stałym punktem porządku naszych spotkań były:

- wyjątkowo rzadkie starodruki odzyskane w ciągu dnia. Wśród nich była Utopia Thomasa Moréa drukowana w 1517 roku w Bazylei. Pierwotnie Biblioteka Królewska posiadała także wydanie z Louvain [1516], które ostatni raz widziane było podczas wystawy w Bibliotece Królewskiej latem 1969 roku. Silke Albrecht udało się jednak sprzedać ten egzemplarz w domu aukcyjnym Christie's 7 czerwca 2000 roku. Sprzedaż starodruku przyniosło Silke i jej rodzinie zysk w wysokości 140000 funtów brytyjskich;

- dyskusje na temat możliwych motywów, którymi kierował się Frede Møller-Kristensen, oraz najprzeróżniejszych hipotez dotyczących daty początków kradzieży.

Jeśli chodzi o datę, pierwszy punkt zaczepienia pojawił się po odzyskaniu dwóch duńskich książek o astronomii. Katalog książek z dziedziny astronomii w Dziale Ksiąg Duńskich przeniesiony został z magazynu w głównym budynku Biblioteki Królewskiej do innego gmachu pod innym adresem w Kopenhadze, do którego już Frede Møller-Kristensen nie miał dostępu. Jak udało się ustalić, zbiory astronomiczne przeniesiono w latach 1968-1969. Ponieważ Frede otrzymał stanowisko bibliotekarza naukowego w roku 1967, a później awansowany został na stanowisko kierownika działu w roku 1969, założyliśmy, że musiał rozpocząć swoją przestępczą 
działalność niemal od pierwszego dnia swojego zatrudnienia w Bibliotece Królewskiej. Konstatacja ta była zarazem fascynująca i przerażająca. Muszę przyznać, że ani dyrektor Nielsen, ani ja nie zdobyliśmy się na końcowe podsumowanie. Nie dlatego, że nie zgadzaliśmy się co do konkluzji, ale dlatego że ten problem bez końca zastanawiał nas i zadziwiał. Nadal jeszcze od czasu do czasu dyskutujemy na ten temat. Odnalezienie dziewięciu atlasów, które zaginęły w sobotę, 13 października 1975 roku, było kolejnym przypadkiem, bardzo intensywnie poruszanym w naszych rozmowach. Atlasy były udostępniane w czytelni Działu Map i Atlasów i przeglądane w piątek, 12 października 1975 roku przez norweskiego badacza, ale kiedy ponownie poproszono o ich udostępnienie $\mathrm{w}$ poniedziałek, 15 października, pracownicy działu nie mogli już ich odnaleźć. Wyjaśnienie tego przypadku przekazano policji, a dalsze dochodzenie prowadzone było też przez Interpol.

W maju 1976 roku jeden z zagubionych atlasów, jak się zdawało, pojawił się w Paryżu. Jedna z naszych specjalistek z Działu Map natychmiast udała się do Paryża, eskortowana przez oficera policji z Kopenhagi. Po powrocie zarzekała się, że egzemplarz atlasu, który jej pokazano, był identyczny z tym, który został wcześniej skradziony z Biblioteki Królewskiej, choć nie było na nim żadnego znaku własności, który posłużyłby za dowód, że Biblioteka Królewska jest jego prawowitym właścicielem. Nie byliśmy więc w stanie tego udowodnić, co było dla nas wtedy bardzo frustrujące, bo nadal byliśmy przekonani, że egzemplarz na pewno pochodził z Biblioteki Królewskiej. A jednak myliliśmy się! Wszystkie zaginione dziewięć tomów odnaleziono w domu wdowy po Kristensenie 5 listopada 2003 roku. Przypadek ten dobrze ilustruje fakt, jak trudno jest zidentyfikować skradzione książki, kiedy już wydostaną się z biblioteki i pójdą w świat. W czasie przeszukania domu wdowy po Kristensenie odnaleziono także kompletny zestaw narzędzi do oprawy i konserwacji książek. Odkrycie to przyniosło odpowiedź na pytanie, dlaczego Frede Møller-Kristensen zawsze wykazywał takie zainteresowanie konserwacją restauracją i opieką nad zbiorami ksiąg Działu Orientalnego. Do tej pory, tj. do jesieni 2003 roku, zawsze uważano to za przejaw „dobrej profesjonalnej praktyki”. Teraz jego entuzjastyczne wręcz zaangażowanie $\mathrm{w}$ ten obszar pracy bibliotekarskiej odczytano inaczej. Jego prawdziwą intencją było poznanie najlepszych sposobów na usunięcie znaków, pieczęci, sygnatur i innych charakterystycznych oznaczeń, które mogły wskazywać na pochodzenie danej książki. Ten temat długo i intensywnie dyskutowaliśmy z dyrektorem Nielsenem.

Całą sprawę udało nam się zachować w tajemnicy do 9 grudnia 2003 roku. Tego dnia Irlandczyk postawiony został przed sądem, a pani 
adwokat, która go reprezentowała, zażądała jego natychmiastowego zwolnienia. Sąd jednak odrzucił ten wniosek, a prasa natychmiast dowiedziała się o sprawie. Nie twierdzę, że to pani adwokat była źródłem przecieku do prasy, byłoby to bowiem złamaniem prawa, jako że jej klient, technicznie rzecz biorąc, pozostawał $\mathrm{w}$ odosobnieniu $\mathrm{w}$ areszcie, więc naruszeniem prawa byłoby ujawnienie nazwiska podsądnego czy też charakteru sprawy prasie lub komukolwiek innemu. Rozgłos oznaczał dla nas nowe trudności, co w konsekwencji spowodowało kolejne opóźnienia. Zarówno bowiem policja, jak i biblioteka zmuszone zostały teraz do zajęcia stanowiska i odpowiedzi na mniej lub bardziej zbędne pytania. Od tego dnia uwaga mediów, a wkrótce - jak się okazało - także kręgów politycznych skupiła się na naszej sprawie. Był to zupełnie nowy aspekt całej tej historii, może nie tyle zaskakujący, ile stawiający nas w zupełnie nowej sytuacji. W konsekwencji dyrekor Nielsen został zmuszony do opublikowania artykułu w duńskim dzienniku "Jyllands Posten", w którym opisał całą historię. Tytuł artykułu brzmiał Anatomia kradzieży ksiażek. Na niewiele się to jednak zdało: cała sprawa toczyła się już swoim biegiem w mediach, a my musieliśmy przygotować obszerne i wyczerpujące sprawozdanie dla Ministerstwa Kultury, w którym wyjaśnialiśmy i opisywaliśmy zarówno aktualny stan rzeczy, jak i przebieg wydarzeń. Było to konieczne, bowiem media, a przy okazji kilku polityków, dla własnych celów mieszali przeszłość z teraźniejszościa, tak że nasze próby wyjaśnienia sprawy przedstawiano teraz jako skandal. Nie chcę tu marnować czasu na zajmowanie się tym prostackim i niegodnym zachowaniem prasy i polityków. W maju 2004 roku cała czwórka sprawców przestępstwa otrzymała wyroki skazujące na pobyt $\mathrm{w}$ więzieniu. Sześćdziesięciodziewięcioletnia wdowa została skazana na dwa lata więzienia, jej syn na trzy lata, a Irlandczyk i synowa na dwa i pół roku każde. Jako okoliczność łagodzącą wzięto pod uwagę fakt, że Silke Albrecht i Thomas Møller-Kristensen mieli dwuletnie dziecko, a wdowa prawie 70 lat.

\section{Wnioski dotyczące bezpieczeństwa zbiorów}

Ważne są środki bezpieczeństwa, które w zamyśle mają służyć ochronie zbiorów, książek, rękopisów i innych cennych przedmiotów znajdujących się w posiadaniu starych bibliotek przed ich kradzieżą lub zniknięciem. Prawda jest jednak taka, że kiedy zbiory znikną, niełatwo jest je odzyskać. Poniżej przedstawiam w punktach niektóre z najbardziej istotnych doświadczeń i trudności, jakim należy stawić czoła w podobnej do naszej sprawie. 
1. Niezwykle trudne jest dochodzenie na drodze prawnej praw do własności skradzionych ksiąg, jeśli trafią na rynek, tzn. pojawią się $\mathrm{w}$ domach aukcyjnych lub antykwariatach. Znaki własnościowe, pieczęcie lub inne oznaczenia bardzo często zostają zręcznie usunięte, co oznacza, że domy aukcyjne, antykwariaty lub inni kupujący zwykle obracają skradzionymi egzemplarzami w dobrej wierze.

2. Nie można problemu upublicznić, bo to zwykle pozbawi policję i bibliotekę możliwości sprawnego dochodzenia i wyjaśnienia sprawy. Doświadczenie pokazuje, że prasa i politycy po prostu wykorzystują takie sytuacje wyłącznie do swoich partykularnych celów. W przypadku gazet i mediów jest to chęć sprzedania czytelnikom skandalu i sensacji, w przypadku polityków celem jest próba wyrazistego publicznego zaistnienia, co zazwyczaj pomaga w kolejnych wyborach.

3. W naszym przypadku ofiarami przestępstwa padły dwie strony: Biblioteka Królewska, z której ukradziono starodruki, oraz zaangażowane domy aukcyjne, które zostały zwyczajnie oszukane. Pieczęcie, znaki własnościowe i inne dowody świadczące o pochodzeniu książek lub też wskazujące na związek danej książki z Biblioteką Królewską zostały pieczołowicie usunięte, zanim Frede Møller-Kristensen przygotował je do sprzedaży. W swoim domu w piwnicy posiadał kompletnie wyposażony warsztat konserwatorski i trzymał zbiór całkiem profesjonalnych narzędzi introligatorskich, którymi potrafił się posłużyć.

4. Międzynarodowe ustawodawstwo dotyczące nielegalnego handlu własnością kulturalną jest, mówiąc bardzo łagodnie i dyplomatycznie, nieścisłe i zbyt niedookreślone, aby mogło odgrywać ważną rolę $\mathrm{w}$ międzynarodowej walce $\mathrm{z}$ tego rodzaju przestępstwami i odzyskiwaniu kradzionych książek czy ich restytucji do ich prawowitych właścicieli.

5. Publiczna, prawna kontrola nad domami aukcyjnymi i handlem antykwarycznym jest o wiele za słaba. W opisywanym przypadku jej faktyczny brak opóźnił rozwiązanie sprawy - dom aukcyjny Christie's zdecydował się ujawnić tożsamość pośrednika dopiero po przedstawieniu przez brytyjską policję decyzji sądowej. W tego typu sprawach całkiem prawdopodobna mogłaby być sytuacja, w której skradzione książki zostałyby zwrócone pośrednikowi, gdy dom aukcyjny przygotowujący aukcję lub antykwariusz nabraliby podejrzeń co do ich legalnego pochodzenia. Gdyby do tego doszło, biblioteka i policja byłyby bez szans na odzyskanie skradzionej własności.

6. Bliższa współpraca pomiędzy światem antykwariuszy a bibliotekami wydaje się absolutnie konieczna, ale towarzyszyć temu musi 
warunek, że antykwariusze zajmujący się handlem starodrukami oraz domy aukcyjne z większym zrozumieniem i otwartością podejdą do realiów i norm rządzących codzienną praktyką biblioteczną.

7. Biblioteki są instytucjami publicznymi i powszechnie dostępnymi dla obywateli, tymczasem domy aukcyjne są prywatnymi przedsięwzięciami, których jedynym zadaniem jest zarabianie pieniędzy dla siebie i pośredników wykorzystujących oferowane przez nie usługi.

Jak już wspomniałam, w naszym przypadku dwie strony były poszkodowane: dom aukcyjny Christie's i Biblioteka Królewska. Nasuwa się zatem pytanie, w jaki sposób biblioteki miałyby oznaczać lub opisywać swoje cenne materiały, by druga strona, np. dom aukcyjny, mogła łatwo ustalić biblioteczną proweniencję oferowanych jej rzadkich starodruków lub rękopisów. Do tej pory jedynym publicznym rejestrem ksiąg bibliotecznych były biblioteczne katalogi. Celem katalogu bibliotecznego jest, po pierwsze, zarejestrowanie, jakie księgi lub inne dokumenty znajdują się w posiadaniu biblioteki, oraz, po drugie, ułatwienie dostępu do nich badaczom. Oznacza to, że opisy tych ksiąg w katalogu bibliotecznym są często bardzo skromne. Wiele katalogów bibliotecznych to po prostu katalogi skróconych tytułów, których praktycznym zadaniem jest umożliwienie ich zweryfikowania i lokalizacja na półce w magazynie. $Z$ drugiej strony, katalog aukcyjny zwykle nie ujawnia żadnych śladów, które mogłyby połączyć dany egzemplarz książki z jakąkolwiek biblioteką. Intencją katalogów aukcyjnych jest promowanie sprzedaży woluminów wystawionych na aukcje, a to oznacza, że podawane informacje mają przede wszystkim uczynić daną książkę atrakcyjnym towarem dla kolekcjonera lub badacza. Eksponują więc informacje o jego rzadkości na rynku, antykwarycznej wartości. To, co ma znaczenie dla bibliotekarza: pieczątki, napisy proweniencyjne, antykwariuszy interesuje mniej, zbywają je ogólnikowymi uwagami, w rodzaju: „niezidentyfikowany właściciel” albo „z kolekcji prywatnej.” Dlatego biblioteka ma olbrzymie trudności z identyfikacją danej książki jako egzemplarza, który został skradziony z jej zbiorów. Tymczasem w czasie poszukiwania skradzionych ksiąg szczegółowe dane dotyczące ich autorów, tytułów itd. nie są szczególnie pomocne $\mathrm{w}$ dochodzeniu policyjnym. Kiedy zgłaszamy kradzież rzadkiej książki oficerowi policji, jego pierwsze pytania będą brzmiały: Jak ona wygląda? Czego powinniśmy szukać? W takim przypadku bibliotekarz zwykle nie będzie w stanie podać sensownej odpowiedzi. Wyjaśnienie przypadku kradzieży z lat 70. ubiegłego wieku i nowe cyfrowe technologie umożliwiły nam jednak stworzenie całkowicie nowego instrumentu: Królewskiego Znaku Identyfikacyjnego. Jest to 
galeria obrazów przedstawiająca cechy charakterystyczne oprawy, pieczęci, znaków własnościowych i sygnatur z Biblioteki Królewskiej, co umożliwia dzisiaj powiązanie danej książki z biblioteką.

Przeł. Tomasz Olszewski

\title{
JESPER DÜRING JØRGENSEN
}

\section{The Anatomy of a Crime Discovery after 25 Years. A Notable Case of Book Theft and its Detection}

\begin{abstract}
Aвstract: The 11th September 2003 was quite an ordinary working day in the Royal Library - at least for the first few hours in the morning. At approximately 11.00 a.m., however, I was interrupted by the telephone. A polite lady introduced herself as the rare book specialist from Christie's in London. From a consignor she had received the following work for sale: Propalladia de Bartholome de Torres Naharro. Dirigida... Napoles: por Ioan Pasqueto de Sallo, Naples 1517. Her investigation of a critical edition of Torres Naharro's works from 1943 had established that only two copies of this particular work were known to exist. One incomplete copy in the National Library of Spain in Madrid, and one complete copy in The Royal Library in Copenhagen. This puzzled the keeper of books at the auction company, and she was keen to know whether she had a historic sensation in her hands or simply a stolen book.
\end{abstract}

KeY worDs: Royal Library in Copenhagen, book theft, old and rare books. 
